\title{
下垂体部腫瘍術後循環動態の恋動
}

\author{
尿崩症，ADH との関連性を中心に
}

下田 雅美·池田公・渋谷 直樹 $\cdot$ 山本 勇夫·津金 隆一・佐藤 修

\section{Postoperative Hemodynamic Changes in Patients with Pituitary Tumors}

\author{
Masami Shimoda, Akira IKEdA, Naoki Shibuya, Isao Yamamoto, \\ Ryuichi TSUGane and Osamu SATO \\ Department of Neurosurgery, Tokai University, Isehara, Kanagawa
}

\begin{abstract}
Antidiuretic hormone (ADH) affects both diuresis and pressor functions, and recent studies have shown hemodynamic changes after its administration. The authors studied postoperative hemodynamic changes in 10 patients with pituitary tumors and examined the correlations among diabetes insipidus (DI), serum ADH, biochemical parameters, and hemodynamics. Systemic vascular resistance (SVR) was significantly lower in patients when they are in DI stage than in non-DI stage. On the other hand, the cardiac index (CI) was higher in patients when they are in DI stage. There were no significant differences between the two groups in central venous pressure or pulmonary capillary wedge pressure. Regardless of whether DI was temporary or permanent, the CI increased and SVR decreased immediately after surgery and, within a few days, returned to the preoperative status. These postoperative hemodynamic changes were the same as those routinely encountered after surgery. These results suggest that fluctuation in ADH after transsphenoidal surgery in patients with DI does not cause hemodynamic changes. Such changes are evidently prevented by various physiological autoregulatory mechanisms.
\end{abstract}

Key words: pituitary tumors, diabetes insipidus, hemodynamic change

\section{I はじめに}

従来, 脳神経外科領域では antidiuretic hormone (ADH) の生理作用として抗利尿作用のみが注日されがらで，るる 一つの生理作用で茄る血管收縮・昇王作用について梳関心 度が低かったと言わざるをえない。しかし，最近，高血圧 症の原因としてはもち万ん，その投与以上る末梢血管抵抗 の増加を巾心上した循環動態の变動に関古る多数の報告が なされている17,24).今回著者らは，逆に，その $\mathrm{ADH}$ が生 理的に低下した状態として㽷崩拝に注日し，下垂体部腫瘍 に対与る経蝶形骨洞手術を施行した证例に関し，術前後の 循環動態をSwan-Gantzカテーテルを用いて測定し，特に
末梢血管抵抗とADH 值抢よび尿崩症との関軏などを検討 したので報告なる。

\section{II 対象および方法}

1985年10月より1986年8月末での11カ月間に下正体部腫 瘍の䛦断を受け，経蝶形骨“洞腫湯摘出術を施行された10例 (Table 1)について，術前上り経皮的に鎖骨下静脈穿刺に よりSwan Gantz力テーテルを挿入し，循環動態の測 定，血液生化学求よびホルモン検查を同特に施行した。 心 拍出量(CO)は Cardiac Output Computer (Hoyer Bremen 社製)に上り測定し，平均動脈平(MAP)，平均肺動脈圧 (MPAP)，肺動脈契入开（PCWP），中心静脈压(CVP)を 
Table 1 Clinical summary of 10 patients with pituitary tumors treated via transsphenoidal surgery

\begin{tabular}{|c|c|c|c|c|c|}
\hline $\begin{array}{l}\text { Case } \\
\text { No. }\end{array}$ & $\begin{array}{l}\text { Aget } \\
\text { Sex }\end{array}$ & $\begin{array}{l}\text { Excess } \\
\text { hormone }\end{array}$ & $\begin{array}{c}\text { Preoperative } \\
\text { hypo- } \\
\text { pituitarism }\end{array}$ & $\begin{array}{l}\text { Operative } \\
\text { finding }\end{array}$ & Remarks \\
\hline 1 & $27 / \mathrm{M}$ & $\mathrm{GH}$ & negative & adenoma & temporary DI \\
\hline 2 & $57 / \mathrm{M}$ & GH & negative & adenoma & temporary DI \\
\hline 3 & $31 / \mathrm{M}$ & none & negative & adenoma & temporary DI \\
\hline 4 & $60 / \mathrm{M}$ & none & negative & adenoma & temporary DI \\
\hline 5 & $38 / \mathrm{M}$ & none & negative & adenoma & temporary DI \\
\hline 6 & $41 / \mathrm{M}$ & GH & negative & adenoma & \\
\hline 7 & $53 / \mathrm{M}$ & none & negative & adenoma & permanent DI \\
\hline 8 & $41 / \mathrm{M}$ & none & negative & adenoma & temporary DI \\
\hline 9 & $71 / \mathrm{M}$ & none & $\begin{array}{l}\text { panhypo- } \\
\text { pitui- } \\
\text { tarism }\end{array}$ & $\begin{array}{l}\text { cranio- } \\
\text { pharyn- } \\
\text { gioma }\end{array}$ & temporary DI \\
\hline 10 & $53 / F$ & PRL & negative & adenoma & \\
\hline
\end{tabular}

GH indicates growth hormone; PRL, prolactin; DI, diabetes insipidus.

Table 2 Hemodynamic data with and without DI in 10 patients

\begin{tabular}{|c|c|c|}
\hline & Without DI & With DI \\
\hline No. of measurements & 33 & 29 \\
\hline Heart rate (beats $/ \mathrm{min}$ ) & $75 \pm 11$ & $81 \pm 12$ \\
\hline Systolic pressure $(\mathrm{mmHg})$ & $135 \pm 22$ & $141 \pm 19$ \\
\hline Diastolic pressure $(\mathrm{mmHg})$ & $78 \pm 14$ & $87 \pm 13$ \\
\hline MAP $(\mathrm{mmHg})$ & $97 \pm 15$ & $104 \pm 14^{*}$ \\
\hline MPAP $(\mathrm{mmHg})$ & $16 \pm 4$ & $17 \pm 4$ \\
\hline PCWP $(\mathrm{mmHg})$ & $10 \pm 3$ & $11 \pm 2$ \\
\hline $\mathrm{CVP}(\mathrm{mmHg})$ & $6 \pm 3$ & $7 \pm 3$ \\
\hline $\mathrm{CI}\left(L / \mathrm{min} / \mathrm{m}^{2}\right)$ & $2.9 \pm \quad 0.8$ & $4.0 \pm 1.2^{* *}$ \\
\hline LVSWI $\left(\mathrm{g} \cdot \mathrm{m} / \mathrm{m}^{2}\right)$ & $45.3 \pm 13.3$ & $62.4 \pm 19.4^{* *}$ \\
\hline RVSWI $\left(\mathrm{g} \cdot \mathrm{m} / \mathrm{m}^{2}\right)$ & $5.8 \pm \quad 5.8$ & $6.8 \pm 3.1^{* *}$ \\
\hline $\operatorname{SVR}($ dyne $\cdot \mathrm{sec} \cdot \mathrm{cm})$ & $1,663.0 \pm 554.4$ & $1,226.4 \pm 481.8^{* *}$ \\
\hline $\operatorname{PVR}($ dyne $\cdot \mathrm{sec} \cdot \mathrm{cm})$ & $113.2 \pm 68.5$ & $76.4 \pm 52.7^{*}$ \\
\hline$\% \operatorname{MAP}(\%)$ & $98.7 \pm 11.1$ & $108.1 \pm 14.7^{*}$ \\
\hline$\% \mathrm{CI} \%$ & $105.2 \pm 18.8$ & $131.2 \pm 26.3^{* *}$ \\
\hline$\%$ LVSWI $(\%)$ & $106.2 \pm 21.2$ & $125.3 \pm 26.2^{* *}$ \\
\hline$\% \operatorname{SVR}(\%)$ & $96.9 \pm 20.9$ & $87.9 \pm 15.9^{*}$ \\
\hline$\% \operatorname{PVR}(\%)$ & $103.5 \pm 47.1$ & $74.7 \pm 28.5^{* * *}$ \\
\hline
\end{tabular}

Values are means \pm SD. ${ }^{*} \mathrm{p}<0.05,{ }^{* *} \mathrm{p}<0.01$ (vs. without DI). MAP indicates mean arterial pressure; MPAP, mean pulmonary arterial pressure; PCWP, pulmonary capillary wedge pressure; CVP, central venous pressure; CI, cardiac index; LVSWI, left ventricular stroke work index; RVSWI, right ventricular stroke work index; SVR, systemic vascular resistance; PVR, pulmonary vascular resistance. \% MAP, \% CI, $\%$ LVSWI, \% SVR, and \%PVR are percent changes compared with preoperative values.
測定乙，心係数 $(\mathrm{CI})=\mathrm{CO} /$ 体表面棈，全身血管抵抗 $(\mathrm{SVR})=(\mathrm{MAP}-\mathrm{CVP}) \times 80 / \mathrm{CO}$, 肺血管抵抗 $(\mathrm{PVR})=$ $(\mathrm{MPAP}-\mathrm{PCWP}) \times 80 / \mathrm{CO}$, 左室 1 回拍出仕事保数 $(\mathrm{LVSWI})=\mathrm{CI} \times(\mathrm{MAP}-\mathrm{PCWP}) \times 13.6 /$ 心拍数，右室 1 回拍出仕事俰数 $(\mathrm{RVSWI})=\mathrm{CI} \times(\mathrm{MPAP}-\mathrm{CVP}) \times 13.6$ ， 心拍数を算出した。同時に，採血により BUN，glucose，

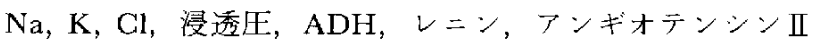
を，库分析として尿比重，尿中尿素窒素(UUN)，Na，K， $\mathrm{Cl}$ 在測定しこれらより $\mathrm{Na}$ clearance $(\mathrm{CNa})=\mathrm{UV} \times$ $\mathrm{UNa} / \mathrm{SNa}(\mathrm{ml} / \mathrm{hr})$, free water clearance $\left(\mathrm{CH}_{2} \mathrm{O}\right)=\mathrm{UV}(1-$ UOsm $/ \mathrm{SOsm})(\mathrm{m} l / \mathrm{min})$, excreted fraction of filtrated so$\operatorname{dium}(\mathrm{FENa})^{23)}=\mathrm{UNa} / \mathrm{SNa} / \mathrm{UUN} / \mathrm{BUN} \times 100(\%)-\mathrm{UV}:$ 単位時間尿量, $\mathrm{UNa}$ : 尿 $\mathrm{Na}$ 濃度, $\mathrm{SNa}$ : 血清 $\mathrm{Na}$ 濃度, UOsm：尿浸透厉，SOsm：血清浸透圧一を算出した。

術後，一過性屯大は完全尿崩症を示した症例は 8 例古 り，その診断基準は(1)時間尿 $300 \mathrm{~m} l / \mathrm{hr} か ゙ 2$ 時間以上，(2) 尿比重1.010以下拈よび尿浸透圧 $300 \mathrm{mOsm} / \mathrm{kg}$ 以下, (3)腎 機能止常, (4)利尿剂不使用とした。また，尿崩症呈した 場合，原則としてピトレッシンは用いず，穴の 1 時問尿量 の50〜60\%吉1/2生理食塩水なは $\mathrm{Na}$ 濃度の低い市股の

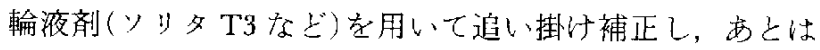
患者の渴感による飲水に任せ, water balance 肪 in over 傾

Table 3 Biochemical findings with and without DI in $10 \mathrm{pa}-$ tients

\begin{tabular}{lrrr}
\hline & Without DI & With DI \\
\hline Blood urea nitrogen $(\mathrm{mg} / \mathrm{d} l)$ & $14.0 \pm$ & 5.2 & $9.9 \pm 4.3^{* *}$ \\
Serum glucose $(\mathrm{mg} / \mathrm{d} l)$ & $184.1 \pm 47.2$ & $198.7 \pm 54.0$ \\
Serum Na $(\mathrm{mEq} /)$ & $137.8 \pm$ & 3.4 & $140.2 \pm 3.9^{* *}$ \\
Serum K $(\mathrm{mEq} / l)$ & $3.8 \pm$ & 0.4 & $3.8 \pm 0.3$ \\
Serum Cl $(\mathrm{mEq} / l)$ & $99.9 \pm$ & 2.4 & $102.7 \pm 3.8^{* *}$ \\
Serum osmolality $(\mathrm{mOsm} / \mathrm{kg})$ & $293.3 \pm$ & 8.6 & $293.7 \pm 15.2$ \\
Urine osmolality $(\mathrm{mOsm} / \mathrm{kg})$ & $464.1 \pm 177.9$ & $206.2 \pm 76.8^{* *}$ \\
Urine urea nitrogen $(\mathrm{mg} / \mathrm{d} l)$ & $457.8 \pm 268.6$ & $170.3 \pm 78.8^{* *}$ \\
Urine Na $(\mathrm{mEq} / l)$ & $94.3 \pm 39.4$ & $57.6 \pm 33.9^{* *}$ \\
Urine K $(\mathrm{mEq} /)$ & $31.5 \pm 16.5$ & $15.8 \pm 6.8^{* *}$ \\
Urine Cl $(\mathrm{mEq} / l)$ & $78.3 \pm 32.0$ & $50.3 \pm 30.4^{* *}$ \\
Urine Na/K & $3.63 \pm$ & 2.44 & $3.92 \pm 2.63$ \\
Na clearance $(\mathrm{m} l / \mathrm{hr})$ & $1.68 \pm$ & 1.23 & $3.17 \pm 1.89^{* *}$ \\
FENa $(\%)$ & $2.8 \pm$ & 2.7 & $2.7 \pm 2.5$ \\
Free $\mathrm{H}_{2} \mathrm{O}$ clearance $(\mathrm{m} l / \mathrm{min})$ & $-0.82 \pm$ & 0.85 & $4.0 \pm 5.9^{* *}$ \\
Serum ADH $(\mathrm{pg} / \mathrm{m} l)$ & $5.9 \pm$ & 5.3 & $3.9 \pm 1.8$ \\
Serum renin $(\mathrm{ng} / \mathrm{m} l / \mathrm{hr})$ & $1.3 \pm$ & 1.2 & $1.7 \pm 1.4$ \\
Serum angiotensin II $(\mathrm{pg} / \mathrm{m} l)$ & $9.2 \pm$ & 4.1 & $11.4 \pm 11.3$ \\
\hline
\end{tabular}

Values are means $\pm \mathrm{SD} .{ }^{*} \mathrm{p}<0.05,{ }^{* *} \mathrm{p}<0.01$ (vs. without DI). FENa indicates excreted fraction of filtrated sodium; ADH, antidiuretic hormone. 

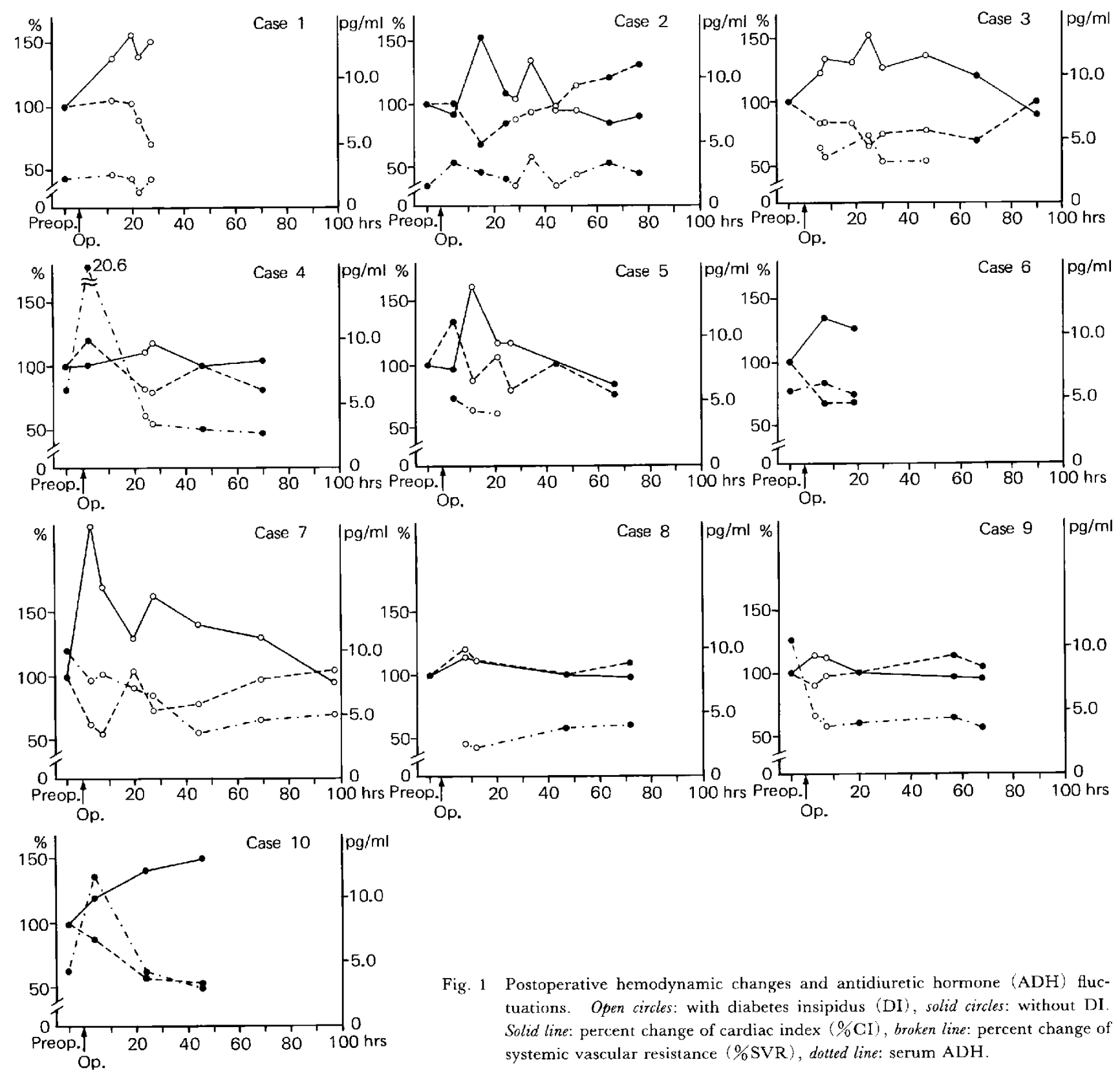

Fig. 1 Postoperative hemodynamic changes and antidiuretic hormone (ADH) fluctuations. Open circles: with diabetes insipidus (DI), solid circles: without DI. Solid line: percent change of cardiac index $(\% \mathrm{CI})$, broken line: percent change of systemic vascular resistance (\%SVR), dotted line: serum $\mathrm{ADH}$.

向になら双よらに注意した。術後のステロイドの補充は，

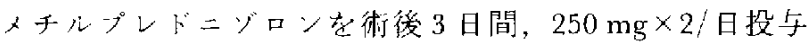
し，以後中止した。これに上り，術後約 4 日間の観察期間 中に副腎機能不全を呈した症例は認めなかった。

\section{III 結 果}

各症例の個々のデー夕を前述の診断基準により，水能远 を示した時期のデー夕群[DI (十)]と示さなかった時期の

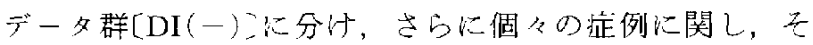

の術徯偱環動態の変動と承崩症との関連を検討した。

\section{1. 尿崩症の有無による比較}

循環動態(Table 2)：循環血液量の指標とたるPCWP,

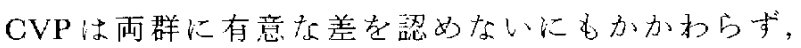
DI（+)群ではCI, LVSWI, RVSWI, MAP が有意心高く, SVR, PVR が有意汇低い hyperdynamic な偱環動態を示し た。なお，各症例により術前值が大分異なるため，变動率 を算出し检討したが，同様の結果であった。

血液・尿化学検査 (Table 3)：DI (十)群で有意に血清 
$\mathrm{Na} \cdot \mathrm{Cl}$ 抢よび $\mathrm{CH}_{2} \mathrm{O}, \mathrm{CNa}$ が高く， $\mathrm{BUN} ，$ 作浸透生， UUN，疗中 $\mathrm{Na} \cdot \mathrm{K} \cdot \mathrm{CI}$ が低い結果と攵った。FENa は両 群の間汇有意差家認めな加った。

ホルモン検査(Table 3)：ADHはDI(十)群で低值であ るものの，有意差を認めず，レニン，アンギオテンシンII の両者も両群に有意差を認め放かった。

\section{2. 各症例別の経時的变化}

Fig. 1 は，各症例別にCI，SVRの術前值を100\%をした 変動彎㧍よび $\mathrm{ADH}$ 值の術後の経時的变化を示す，尿崩症 を示した症例〈症例 1〜5,7〜9〉)持よび示さ斿かった症例

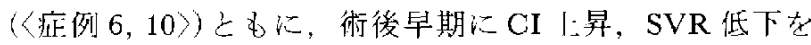
示し，経過の follow-up が不十分であった〈症例 1，6，10〉 を除き，術後40１000時間で術前值に復する傾向を認めた， この傾向は完全层崩症を古した〈症例 7〉です同様であり， 尿崩泟の有無上の間组関連はないようである。ADH 值は 術直後の測定で高值を示吉ことが多いが，その術後変動に 一定の傾向はなく，CI, SVRはもちろん，他の循環動態 の指標上の間飞和らかな相関仕認めなかった。これらの

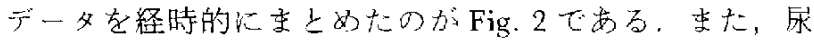
中 $\mathrm{Na}$ 濃度，FENa，CNaの経時的変化飞，定の攧向はな く，個々のデータとの比較を含め，循環動態との間に相関
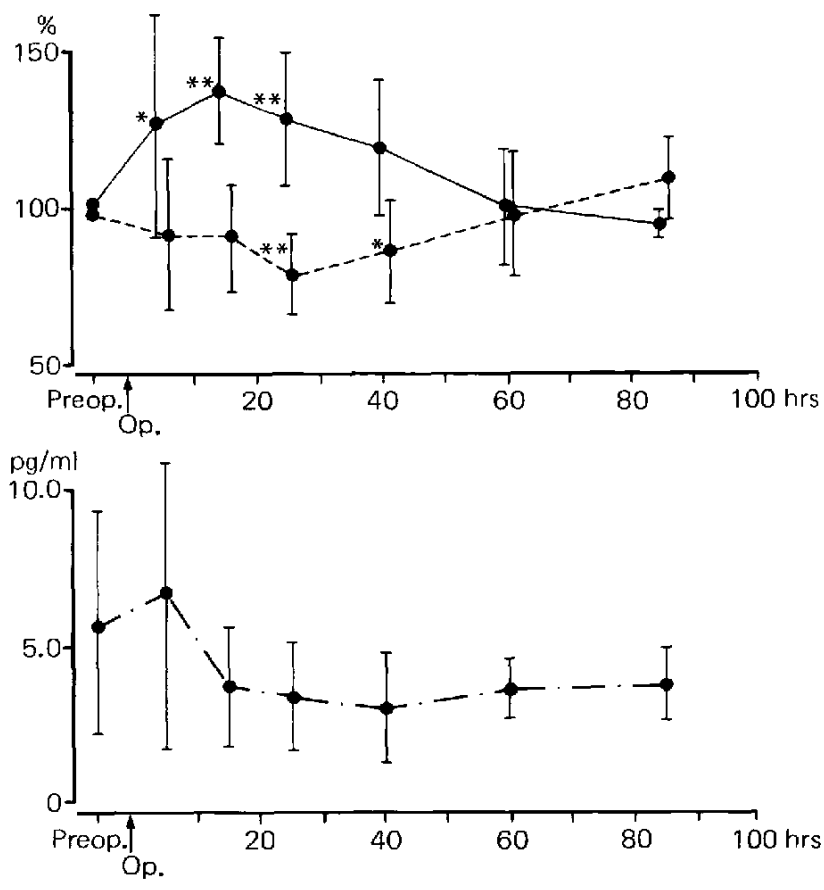

Fig. 2 Mean postoperative changes in hemodynamics and serum ADH. Solid line: \% CI, broken line: \% SVR, dotted line: serum $\mathrm{ADH}$. Values are means $\pm \mathrm{SD} .{ }^{*} \mathrm{p}<0.05$, ${ }^{* *} \mathrm{p}<0.01$ (us. preoperative values).

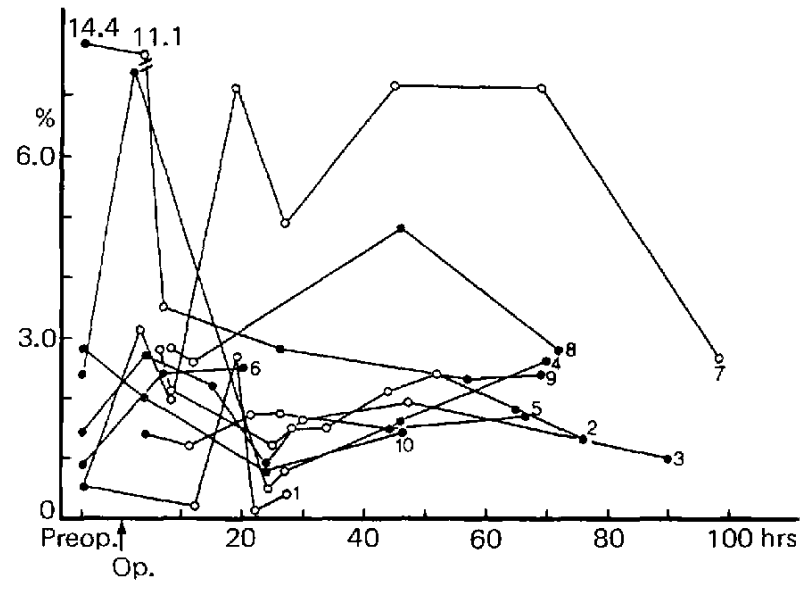

Fig. 3 Postoperative changes in excreted fraction of filtrated sodium (FENa). Open circles: with DI, solid circles: without DI. Numerals at the right of the lines are Case numbers. Please note that the two values in the upper left corner are out of scale.

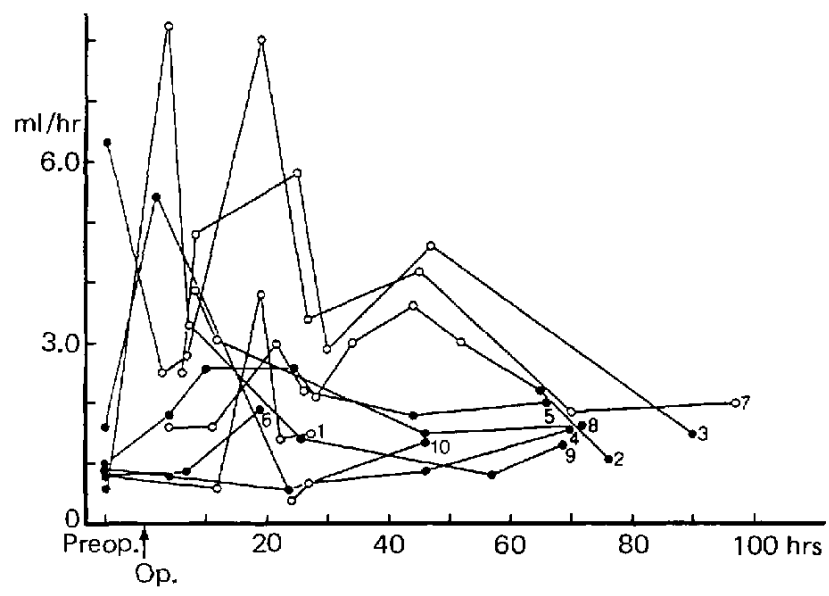

Fig. 4 Postoperative changes in Na clearance. Open circles: with DI, solid circles: without DI. Numerals at the right of the lines are Case numbers.

は認めなかった(Fig. 3，4)。一方，レニン，アンギオテン

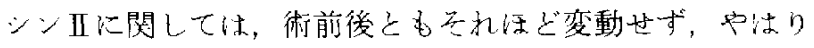
循環動態との間汇相関を認め沈かった（Fig. 5, 6).

\section{$\mathrm{N}$ 考察}

$\mathrm{ADH}$ の生理的作用には抗利尿作用の活心に昇圧・血管 収縮作用があり, 最近, 㣪者に関し, 特汇高血压症の多数 因子の一つとして，その存在が注月されている

Padfield $5^{(6)}$ は悪性高血圧症の患者の血清 ADH 值を検討 し，此常人上り高値であること示した。 しかし，血比々 


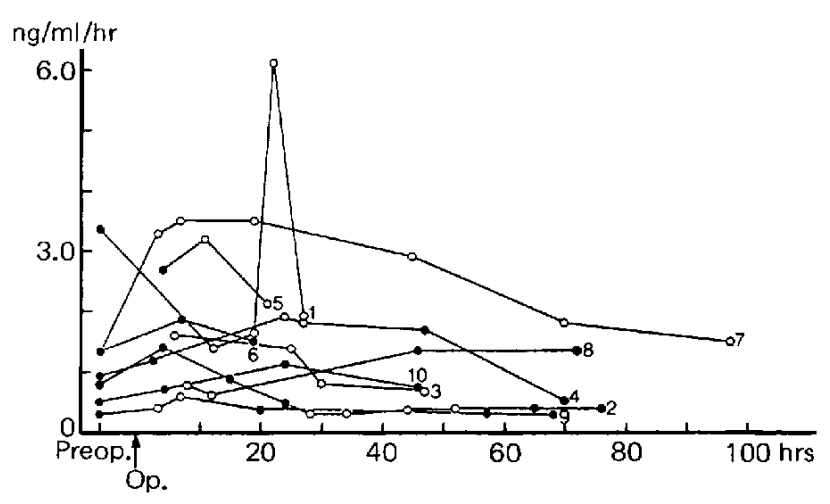

Fig. 5 Postoperative changes in serum renin. Open circles: with DI, solid circles: without DI. Numerals at the right of the lines are Case numbers.

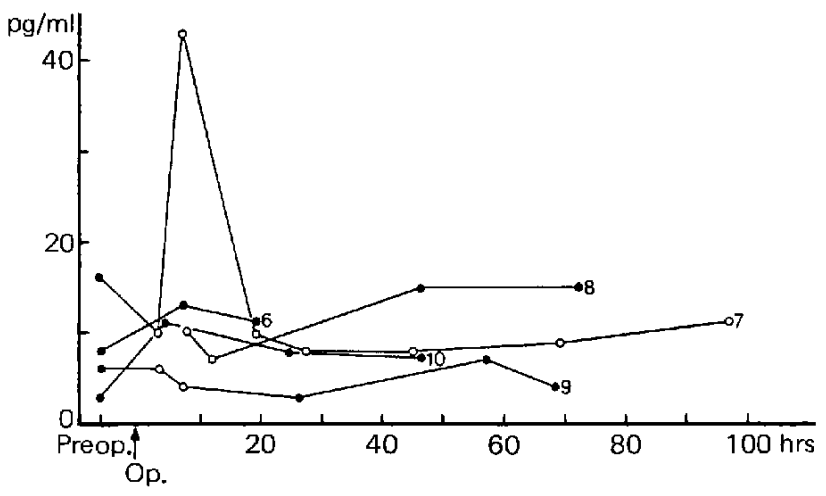

Fig. 6 Postoperative changes in serum angiotensin II. Open circles: with DI, solid circles: without DI. Numerals at the right of the lines are Case numbers.

$\mathrm{ADH}$ 測定值との閒に明らかな相関隹なく，正常人に $\mathrm{ADH}$ を投与し，要性高血圧泟患者の $\mathrm{ADH}$ 值と可程度に ト昇させても血圧の上昇仕認めなかったといら。さらに， $\mathrm{ADH}$ 分泌異常症候群を呈した患者の $\mathrm{ADH}$ 值致患性高血

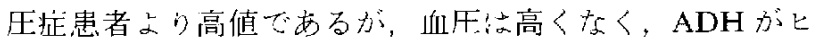
トに招いて昇圧效果を示すにはかなりの血中レベルを必要 とすると結論した，吉出ら年によれば，実際にADHによ る昇压作用が問題となるのは，Shy-Drager 症候群(3)の上 与に頸動脈洞，大動脈宁に存在する王受容体を介する血生 調節機構が自律神経機能障害に上り破綻した昜合上，他の 昇什ホルモンが上昇し，昇止作用が増強される場合が考え

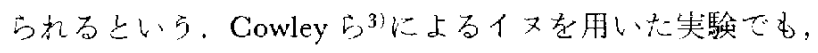
少量の $\mathrm{ADH}$ を投与するとdose-dependent 以末梢血管抵抗 は增加するが， $\mathrm{CO}$ ，脈拍数は忧受容体を介した血压調節 により逆に低トし，血圧はその相殺作用により変化寺さ

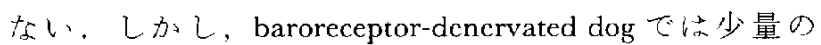

$\mathrm{ADH}$ 投与により血圧が」昇すると報告している。

逆に，尿崩症など，生理的 $\mathrm{ADH}$ 濃度の低下した状態に

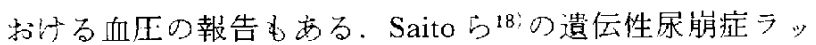
トを用いた実験によると， deoxycorticosterone acetate 投 与し，食塩負荷に上って飼育したラットに抌いでッンプ ッシン投与虻高血压発症に不可欠で，この型の高血压症 ットにバンプレッシンの血管收縮作用方よび抗利尿による 循環血液量の增加が関与していること示した，また，吉

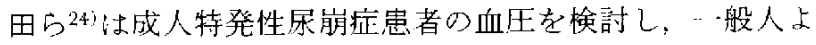
り低い傾向にあったとしている。ささらに、イヌに Һypo-

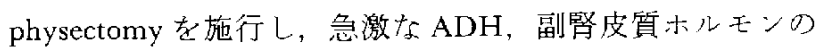
低下をきたした場合に血管平滑筋の弛緩を生じたとする報

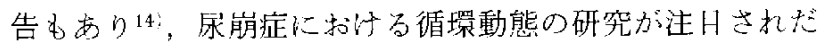

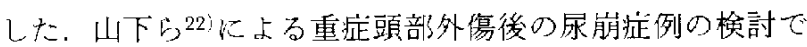
结，ピトレッシン投与・非投与例の比較において，非投与 例ではPCWP, CVPがともにやや低值であるに市かかわ らず，SVR，PVRが著明低下して抵り，ピトレッシン

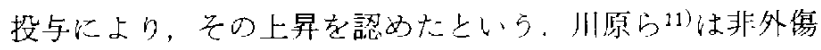
性尿崩症の偱環動態を榆討し，ピトレッシン投与前後にお いて同様の結果を得たが，血清 ADH 值との相関は認めな かかたといら。しかし、いずれの報告にても barbiturate， dopamineなどの薬剂が投与されている症例む多く，また 患者の止常时の循環動態との比較ではなく，ピトレッシン 投与前後の变化についてのみの比較であった。

本稿の著者らの下垂体部腫瘍手術前後の腯㻴動態の検討 に上ると，確か心測定时の疗崩症の有無による比較では疛 崩症呈した群に扣いて有意化SVR, PVRが帒く，拓 らくそのため相詨的に，あるいは血在調節機構を介した代 償作用により CI が帛いhyperdynamicな循環動態を示し たものと考えられる。しかし，各症例別に術前後の経時的 変化を検討すると，我崩症を古した症例も呈さなか心た症 例与，さらに完全尿崩症を呈し，術後疗崩症状態か持続し た症例でさ之，術媵早期にSVR 低下，GI上昇孝示し， 以後術前值に復する䝨向を涩め大。これをでも手術による CI の変動に関する報告は多く，食道癌の手術など，手術

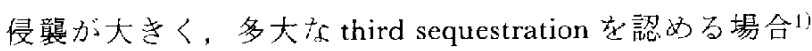
性别として，一般的手術においては，術中は麻酔，低体温 などにより酸素消費量が低下し，酸素负倩抏よびCI低下 を生ずるが，術後てれらを代償するためにCI が早期上り 堌加し，数日㣪に術前值に復るるとされている わち, 今吅著者らの経験した下垂体部腫瘍術後の偱環動態 の変動以，ADH 低下による末梢血管抵抗の減少火起因 L たものではなく，一般的手術後り循環動態の変動と同様な 一Dの surgical stress と考克るのが妥当で，測定時の尿崩 症の有無による有意差は，単に一過性康崩症を呈した怔例 
が多く，尿朋症発現が術㣪早期に集中したためと思われ t.

さらに, 本研究てはこの循環動態の変動と $\mathrm{ADH}$ 值との 相関性を認めなかった。しかし，松角ら ${ }^{12}$ 沬ADHの測定 について，月内変動，体位との関連も含めて，分泌がきわ めて episodic かつ短時間に变化するため，測定值と臨床像 との間に有意な相関を示さないことがあると述べており， $\mathrm{ADH}$ を投与し，それに上る循噮動態の変動を検討する場 合と比較し，低下したADH 值との相関を検討する場合， $\mathrm{ADH}$ の測定䛊差を含め，かなりの困難さが生ずる可能性 が势る。さらに，トルコ鞍近傍手術音含め大脳神経外科手 術侵襲によっても，一般的手術後之同様に血清浸透生，血 压上関連しない，術值後の $\mathrm{ADH}$ 過量放出がある点10;，史心 手術そのものによる循環動態の変動が市ることなどを考え 合せると，多数因子の複合した現象で茄吕ことは明らかで あり，単純に $\mathrm{ADH}$ と循環動態との関連を求めること自 体，不適切であるとの可能性も考兄られる。

今回の著者らの研究対象となった卜垂体部腫瘍に対与る 経蝶形骨洞手術後に批いて泣，尿崩症を呈したとしても意 識障害を認めず，患老の渴感が障害されることもま机なた め，点滴，领水に上る尿量の追い掛计補正行与こ上化上 り normovolemic Kコントロールすることは比挍的容易 こ，血生調節機構の障害もなく，ADH の変動，特に低下 に対し, 種々の autoregulation 機構が十分に作動可能な状 熊であったと考兄られた。しかし，術娞早期り CO增加 は術中の酸素負倩を代償する生体防御反底であり，同時心 术梢血管抵抗子減少し，相対的 hypovolemia この時期に，尿崩症といら多尿によって循環血液量を保て 泫くなるといらことは，心・肺機能への負担を増大させ， 止常な生体反底を損ならことにも店ること资十分把握し， 水分管理をすべきと思わ机る。一力，意識障害患者，渴中 枢の障告された患者など，渴感を一つの指標として管理す ることができず，normovolemia を保つのが困難な症例， 屯大は多量出血を伴った多発外傷例や過度の osmotic therapyにより脱水を呈した例など，著明な hypovolemia を認める症例，自律神経障害例，ADH以外江内分泌障 害を認好症例などに尿崩症を合併した場合，尿崩症によ るADH の変動比対する autoregulation が崩れる可能性が 強く, 種々の循環動態の变動を生ずる危険性があり，今後 の研究課題之思呩る。

最後に，最近 ADH と同様に高血王症の因子として注目 されている Na利尿ホルモンに関し，㛟討してみる。現在，

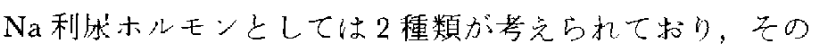

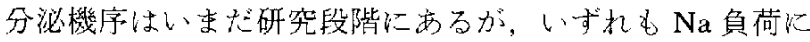
上り分泌が促進さ秃ると考克られている。一つはde
Wardener ららがイ又の交攴灌流実験より腎の Na 排泄因子 として禾球体濾過率とアルドステロン以外第 3 の因子 (third factor)の存在を報告したのに始来り， digitalis と同 様に Na-K ATPase 阻害に上り尿細管飞捄ける $\mathrm{Na}$ 再吸収 阻害し，利尿を起こすホルモンであり，endogenous digitalis-like factor (EDF) とも呼ばれる

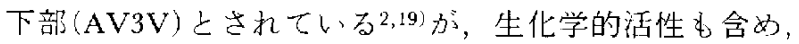
不明な点が多い，他の一つは心房より抽出され，作用機序 はいまだ不明であるが，やはり Na利尿をきたし，心房性 $\mathrm{Na}$ 利尿六ルモン(atrial natriuretic polypeptide: ANP) と呼 ばれるるのである゙).ANPは心房のみならず脳内(視床下 部など)に存在し，から心房内のものとは異なる調節を

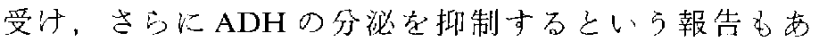
り15,21，EDF含め，こ礼らの分泌機構に対しての下垂 体・視床下部手術による影響が考克られる。また。これら は $\mathrm{Na}$ 利尿のみならず， $\mathrm{EDF}$ は血管平滑筋細胞膜の $\mathrm{Na}^{-}$ K ATPase を抑制することにより血管收縮作用を，ANP は血管桩張作用を持つことより，両者の偱環動態への作用

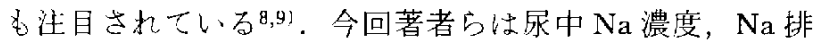
泄率 $(\mathrm{FENa}) ， \mathrm{CNa}$ など、こ机らのホルモンの作用を反映 する factor と循環動態とを比較検討したが，相関性は認め ら机なかった。、ずれの factor \& $\mathrm{Na}$ 利杘ホルモンの及で 調節されている訳ではなく，単一沉は説明できないが，現 在をで烁崩症に招汓る電解質動態はADH を中心とした従 来の視床下部・下垂体系ホルもンについての検討されて きた傾向があり，今後，Na利尿ホルモンの定量的測定と その循環動態の变動の研究が重要であると思わ㧈る。

\section{V 結 語}

1. 経蝶形骨洞手術を施行した下垂体部腫瘍10例飞対 L, 術前後に循環動態および血液・尿生化学検查，ADH などのホルモン測定を施行し，尿崩症との関連を含め，検 討した。

2. 各症例別々循環動態の変動を検討すると，尿崩症発 現の有無存問方ず，完全农崩淽へ移行した例屯含め，術後 早期にCI L昇，SVR低下在生じ，数日内に術前值汇復 した。これらの変動は，一般的手術侵襲後の女の上同様の 機序によるものであると思われた。

3. 本研究刘象任批万我崩症の上う飞，全身状熊良好 で合併怔などなく，単にADHが変動した場合は，種々の autoregulationの働きにより,ADH変動に上る循環動態 变動は生じないと思われた。

4. 循環動態と ADH 扩よび $\mathrm{Na}$ 利永ホルモンの作用 反映すると思わ机る尿中 $\mathrm{Na}$ 排泄率などとの関連は認めな かった。 
5. 視床下部・下垂体系疾患に拀いて， $\mathrm{ADH}$ はもちる ん， $\mathrm{Na}$ 利尿ホルーモンの定量的測起およびそれらと循環動 態との関連性の検討の重要性を感じた。

\section{文献}

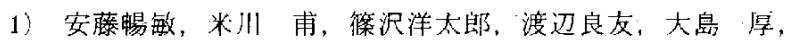
鈴木 博, 大高均, 藤崎真人, 阿部命彦：食道癌患者に拉 ける術前術後の循環動態の变動に関寸る研究. 日外会誌 83 : 624-634, 1980

2) Bealer SL, Haywood JR, Gruber KA, Buckalew VM, Fink GD, Brody MJ, Johnson AK: Preoptic-hypothalamic periventricular lesions reduce natriuresis to volume expansion. $A m J$ Physiol 244: R51-R57, 1983

3) Cowley AW Jr, Monos E, Guyton AC: Interaction of vasopressin and the baroreceptor reflex system in the regulation of arterial blood pressure in the dog. Circ Res 34: 505-514, 1974

4) de Bold AJ, Borenstein HB, Veress AT, Sonnenberg H: A rapid and potent natriuretic response to intravenous injection of atrial myocardial extract in rats. Life Sci 28: 89-94, 1981

5) de Wardener HE, Mills IH, Claphaw WF, Hayter CJ: Studies on the efferent mechanism of the sodium diuresis which follows the administration of intravenous saline in the dog. Clin Sci 21:249258,1961

6) Gruber KA, Whitaker JW, Bachalew VM: Endogenous digitalis-like substance in plasma of volume-expanded dogs. Nature 287: 743-745, 1980

7) Heilbrunn A, Allbritten FF Jr: Cardiac output during and following surgical operations. Ann Surg 152: 197-210, 1960

8) 石井當男, 烃岡博昭, 後藤淳郎, 平田恭信, 杉本徳一郎, 石光俊彦：ナトリウム利尿ホルモンと血正調節。代謝 22: 539-548, 1985

9) Ishii $M$, Matsuoka $H$, Hirata $Y$, Suginoto $T$, Kangawa $K$, Matsuo $\mathrm{H}$ : Effect of $\alpha$-human atrial natriuretic polypeptide ( $\alpha$ hANP) on the main regulatory mechanisms for blood pressure and body fluid volume in rats. Jpn Circ J 49: 969-972, 1985

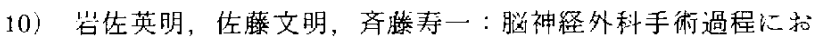
计る下垂体後䒩ホルモン分泌動態. Neurol Med Chir (Tokyo) 21: $583-589,1981$

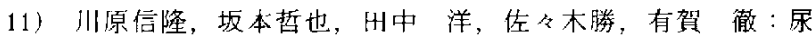
肾症の循謤動態。第42回日本脳神経外科学会総会抄録集. 1983, p 293

12）烃角捸彦，三浦正毅：視床下部侵襲とADHの日内りズム。 脳神外科 10:1029-1039, 1982
13) Möhring J, Glänzer K, Maciel JA Jr, Dusing R, Kramer HJ, Arbogast R, Koch-Weser J: Greatly enhanced pressor response to antidiuretic hormone in patients with impaired cardiovascular reflexes due to idiopathic orthostatic hy potension. J Cardiovasc Pharmacol 2: $367-376,1980$

14) Monas E, Cox RH, Peterson LH: Direct effect of physiological doses of arginine vasopressin on the arterial wall in vivo. $\mathrm{Am} J$ Physiol 234: H167-H172, 1978

15) Morii N, Nakao $K$, Sugawara A, Sakamoto $M$, Suda $M$, Shimokura M, Kiso Y, Kihara M, Yamori Y, Imura H: Occurrence of atrial natriuretic polypeptide in brain. Biochem Biophys Res Commun 127: 413-419, 1985

16) Padfield PL, Brown JJ, Lever AF, Monton JJ, Robcrtson JIS: Blood pressure in acute and chronic vasopressin excess. New EnglJ Med 304: 1067-1070, 1981

17) Rascher W, Lang RE, Unger TH: Vasopressin, cardiovascular regulation, and hypertension, in Ganten D, Pfaff D (eds): Current Topics in Neuroendocrinology, Neurobiology of Vasopressin. New York, Springer, 1985, pp 101136

18) Saito T, Yajima $Y$ : Development of DOCA-salt hypertension in the brattleboro rat. Ann NY Acad Sci 394: 309-318, 1982

19) Songu-Mize E, Bealer SL, Caldwell RW: Effect of AV3V lesions on development of DOCA-salt hypertension and vascular Na-pump activity. Hypertension 4: 575 580, 1982

20) Waxman K, Lazrove $S$, Shoemaker WC: Physiologic responses to operation in high risk surgical patients. Surg Gynecol Obstel 152: $633-638,1981$

21）山出敬行, 中尾一和, 森井成人, 伊藤裕, 塩野尚三, 坂 本誠，菅原 照, 斉藤能彦, 永業正美, 松下 亨, 并村裕

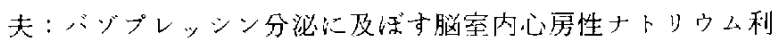
瓜ポりペプチド投与の抑制約果. 日内分泌会誌 $62: 510,1986$

22）山ト雅知，坂本哲也，佐々木勝，堤晴彦，有㖵徹，豊 岡秀訓，三井香児：重症頭部外傷心続発した尿崩症の偱環動 態 Neurol Med Chir (Tokyo) 24: 701-705, 1984

23）横山清七，杉原隆，杉拍輝地，田島知郎，三富利夫，西 村正樹，谷野隆三郎，宮本之昭：広範囲熱傷小児の fractional excretion natrium. 熱傷 7:100-106, 1982

24)吉田尚, 斉藤寿一：ベゾプレッンソによる血圧調節。ホ ルモンと䧄 11:1093-1096, 1983

[別刷請求先：干259-11 神奈川県伊勢原市望星台，東海大学脳 神経外科, 下田雅美] 